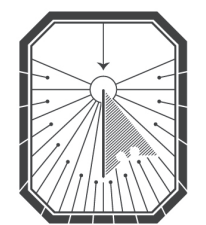

KYIV-MOHYLA

LAW \& POLITICS JOURNAL

KYIV-MOHYLA SCHOLARLY PEER-REVIEWED JOURNALS

Polish Administrative Court's Dissenting Opinions in Excise Duty Cases

Author(s): Patryk Kowalski

Source: Kyiv-Mohyla Law and Politics Journal 6 (2020): 197-220

Published by: National University of Kyiv-Mohyla Academy

http://kmlpj.ukma.edu.ua/ 


\title{
Polish Administrative Court's Dissenting Opinions in Excise Duty Cases
}

\author{
Patryk Kowalski \\ Assistant Professor \\ University of Łódź, Poland
}

\begin{abstract}
This article presents the results of the examination dissenting opinions submitted by judges of administrative courts in excise duty cases in the years 2004-2018. The analysis covers the judgments of all sixteen administrative courts in Poland issued in the abovementioned period. These criteria led to the selection of research material covering a votum separatum from 78 judgments issued by administrative courts on excise duty and 6o judgements issued by the Supreme Administrative Court as a result of filing a cassation appeal against administrative court judgments. By using quantitative analysis in the performed case studies, it has been determined that, for example, administrative court judges extremely rarely submit in cases of excise duty votum separatum - about five times per year. Between 2004 and 2018 out of 19,172 judgments issued only to 78 of them issued a dissenting opinion, which is more or less $0.5 \%$ of the total. In the course of case studies using qualitative analysis it has been observed, for example, that in the constituent part of the justification - the legal basis of the decision and its explanation - the SAC referred to the arguments expressed in a separate opinion in $41 \%$ of judgments.
\end{abstract}

Key Words: excise duty; administrative courts; tax law; dissenting opinion, votum separatum.

\section{Introduction}

Among the issues related to the deliberation on the ruling and voting of judges in administrative court proceedings, the institution of dissenting opinion (latin: votum separatum, contra votum, abbreviated as "cvs") authorizing the judge of the remaining minority to disclose this fact in an appropriate form is of significant importance, despite the fact that the vote was secret. This regulation, although also appearing in civil and criminal procedure, has not been published in many Polish scholarly studies. ${ }^{1}$

1 The most important of tchem include the following: Antoni Bojańczyk, "Zdania odrębne w postępowaniu karnym," Forum Prawnicze 12," (2012): 3-12; Jerzy Bartoszewski, Zdania odrębne w procesie karnym. (Warszawa, 1973); Bohdan Zdziennicki, “Zdania odrębne w orzecznictwie polskiego Trybunału Konstytucyjnego," in Księga XX-lecia orzecznictwa Trybunatu 
The belief that a dissenting opinion is not cognitively interesting remains dominant, because its submission is not of great importance for the decision and represents only the individual interest of the "voting" judge. In addition, in Polish tax law doctrine, quite opposite to that in foreign law, ${ }^{2}$ there are no studies analyzing the functioning of the described institution in practice and its importance in the process of applying this branch of law.

The subject of the research conducted in this work is the analysis of dissenting opinions submitted by judges from the judgments of voivodship administrative courts (further: "VAC") in cases of excise duty.

A dissenting opinion is a statement, an act of will expressed in the form specified by the statute on the part of one of the members of the adjudication panel, different from the majority opinion of its other members. Submission of a contra votum is a procedural act and, for its effectiveness, can be submitted only within the time and form prescribed by the regulations.

The institution of the votum separatum in administrative court proceedings is regulated by Article $137 \S 2$ in fine of the Act of August 30, 2002 Law on Proceedings Before Administrative Courts, ${ }^{3}$ according to which a judge who does not agree with the majority vote may submit a dissenting opinion when signing the judgement and is obliged to substantiate it in writing before signing the justification. Dissenting opinions may also apply to the justification of the judgment itself. The submission of a dissenting opinion shall be made known, while its author's name can be revealed only upon her/ his prior consent.

The most important from the point of view of the subject and purpose of the development function of dissenting opinions - the documentary and guarantee function — should be emphasized. The documentary aspect of the votum separatum is characterized by the fact that its submission is intended to consolidate the fact of nonunanimous voting and the reasons that determined it. In turn, the guarantee aspect of dissenting opinions states that their submission gives the parties the opportunity to familiarize themselves with the opposite argumentation, which led the judge to vote differently on the decision or justification. In addition, the dissenting opinion constitutes an important reference point for the court of second instance, which may, when considering a remedy, resist or negate the arguments contained in cvs. ${ }^{4}$

One major research (cognitive) goal was set in the study. It is the analysis of the functioning of the institution of votum separatum from the judgements of all Polish

Konstytucyjnego, ed. Marek Zubik. (Warszawa, 20o6), 135-58; Maciej Wojciechowski, Spory sędziowskie. Zdania odrębne w polskich sądach. (Gdańsk, 2019).

2 See f. e. Rodney Fisher, "Judicial Dissent in Taxation Cases: The Incidence of Dissent and Factors Contributing to Dissent," eJournal of Tax Research 13, (2015): 470-90; John Adler, "Dissent in Courts of Last Resort: Tragic Choices?" Oxford Journal of Legal Studies 20 (2000): 221-46; Lee Epstein, William. M. Landes, Richard A. Posner, Why (and When)Judges Dissent: a Theoretical and Empirical Analysis. (John M. Olin Law \& Economics Working Paper No. 510, 2010).

3 Consolidated text of Dz. U. 2019, item 2325, as amended, further: "PBAC".

4 Bojańczyk, Zdaniaodrębne, 6-8. 
VACs in practice. An examination of the above will also allow an assessment of the application of tax law by administrative courts in excise duty matters.

Achieving this goal can only occur by solving the main research problem, which was posed in the form of a question: to what extent do dissenting opinions from Polish voivodship administrative court judgments issued in cases of excise duty fulfill the documentary and guarantee function? The main research problem posed in this way was used to formulate the research hypothesis, which reads: dissenting opinions from Polish voivodship administrative court judgments issued in cases of excise duty fulfill the documentary and guarantee function to a large extent.

The legal-dogmatic method of law was used to gather the material necessary to resolve the research problem outlined above. The basic research technique consists of the quantitative and qualitative analysis of the content contained in the collected research material. To implement this technique, research tools such as the Central Database of Judgments of Administrative Courts ${ }^{5}$ and court rulings contained in it were used.

The research included a sample of judgments of all 16 Polish voivodship administrative courts, issued in cases of excise duty, published in the Central Database of Judgments of Administrative Courts (further: “CDJAC”), to which a separate opinion was submitted, issued in the period from January 1, 2004 to December 31, 2018. The sample included rulings browsed against index terms used in the search form, such as "judgment;" "final judgment;" "with a dissenting opinion;" and the thematic slogan"excise duty." 6 These criteria led to the separation of research material covering 78 judgments issued by the VAC regarding excise duty. In addition, the collected research material included 6o SAC decisions issued as a result of a cassation appeal against the judgments of the courts of first instance. SAC rulings were examined only by means of qualitative analysis, which is discussed in more detail in point 6.2.

\section{Quantitative Analysis}

The quantitative analysis of dissenting opinions submitted from VAC judgments in excise duty cases shows that judges submit votum separatum extremely rarely. In the years 2004-2018, voivodship administrative courts issued a total of 19,172 judgments in cases of excise duty. A dissenting opinion only 78 of them was submitted, which

“Central Database of Judgments of Administrative Courts," accessed October 1, 2020, http:// orzeczenia.nsa.gov.pl. This database was launched on 01.10 .2007 in order to create for interested parties' conditions for fullest access to the content of administrative court decisions. It contains all administrative court rulings issued after the day of its launch to November 14, 2018, and most of the rulings that were issued from January 1, 2004 until September 30, 2007. (Information of the Chairman of the Judicial Information Department of the Supreme Administrative Court of 16.12.2019, reference number WIS.050.676.2019, own collection). Voivodship Administrative Court in: Białystok, Bydgoszcz, Gdańsk, Gliwice, Gorzów Wielkopolski, Kielce, Kraków, Lublin, Łódź, Olsztyn, Opole, Poznań, Rzeszów, Szczecin, Warszawa and Wrocław. 
Table 1: "Judgments issued in excise duty cases by voivodship administrative courts in the years 2004-2018 together with separate opinions submitted from them - by years"

\begin{tabular}{|c|c|c|c|}
\hline & & NUMBER OF & \\
\hline & NUMBER OF & DISSENTING OPINIONS & \\
\hline & JUDGMENTS OF & IN JUDGMENTS & \\
\hline & VOIVODSHIP & OF VOIVODSHIP & \\
\hline & ADMINISTRATIVE & ADMINISTRATIVE & PERCENTAGE OF \\
\hline YEAR OF & COURTS IN CASES OF & COURTS IN CASES OF & DISSENTING OPINIONS \\
\hline JUDGMENT & EXCISE DUTY & EXCISE DUTY & ON EXCISE DUTY \\
\hline 2004 & 91 & o & $\mathrm{o}$ \\
\hline 2005 & 113 & o & o \\
\hline 2006 & 434 & o & o \\
\hline 2007 & $1,7 \circ 3$ & o & o \\
\hline 2008 & $1,05^{8}$ & 2 & $0.19 \%$ \\
\hline 2009 & 625 & 1 & $0.16 \%$ \\
\hline 2010 & 866 & 1 & $0.12 \%$ \\
\hline 2011 & 1,404 & 17 & $1.2 \%$ \\
\hline 2012 & $1,66 \circ$ & 6 & $0.36 \%$ \\
\hline 2013 & 2,545 & 25 & o.98\% \\
\hline 2014 & $2,45^{2}$ & 20 & $0.81 \%$ \\
\hline 2015 & 2,894 & 5 & $0.17 \%$ \\
\hline 2016 & 1,902 & o & o \\
\hline 2017 & 854 & 1 & $0.12 \%$ \\
\hline 2018 & 571 & O & $\mathrm{O}$ \\
\hline Sum & 19,172 & 78 & \\
\hline
\end{tabular}

Source: own study based on the CDJAC (accessed: September 30, 2020).

constitutes less than $0.5 \%$ of the total. During the 15 -year study period, dissenting opinions were submitted on average 5.2 times per year.

Dissenting opinions from two judgments in excise duty cases were made for the first time in 2008 out of 1058 judgments issued by all VACs in Poland, which constituted only $0.19 \%$ of all judgments in excise duty issued that year. It should also be noted that in the years 2008-2015, the number of dissenting opinions submitted was the highest, and from 2016 it began to noticeably decrease (in 2016 and 2018 no dissenting opinions were submitted and only one was submitted in 2017).

The largest number of dissenting opinions, as many as 25, were submitted in 2013, however, it was a small percentage of judgments issued in excise duty cases, amounting to less than $1 \%$. Dissenting opinions were not submitted at all in the years 2004-2007 and in the abovementioned 2016 and 2018. It should be emphasized that the noticeably highest percentage of dissenting opinions in excise duty cases was recorded in 2011 (1.21\%). 1,404 judgements were issued in 2011, up to 17 of them dissenting. In turn, the 
Table 2: "Judgments issued in excise duty cases by voivodship administrative courts in the years 2004-2018 together with separate opinions submitted from themaccording to the jurisdiction of the court “

\begin{tabular}{|c|c|c|c|}
\hline & & NUMBER OF & PERCENTAGE \\
\hline & NUMBER OF & DISSENTING & OF DISSENTING \\
\hline VOIVODSHIP & JUDGMENTS IN & OPINIONS IN EXCISE & OPINIONS ON \\
\hline ADMINISTRATIVE & EXCISE DUTY & DUTY RULINGS & EXCISE DUTY \\
\hline COURT & CASES (2004-2018) & $(2004-2018)$ & $(2004-2018)$ \\
\hline Białystok & 391 & o & 0 \\
\hline Bydgoszcz & 789 & 4 & $0.51 \%$ \\
\hline Gdańsk & 1,043 & 3 & $0.29 \%$ \\
\hline Gliwice & 3,329 & 7 & $0.21 \%$ \\
\hline Gorzów Wielkopolski & 1,454 & 1 & $0.07 \%$ \\
\hline Kielce & $5^{22}$ & 1 & $0.19 \%$ \\
\hline Kraków & $45^{2}$ & o & o \\
\hline Lublin & 895 & o & o \\
\hline Łódź & 1,183 & 5 & $0.42 \%$ \\
\hline Olsztyn & 449 & 2 & $0.45 \%$ \\
\hline Opole & 612 & o & o \\
\hline Poznań & 1,969 & 17 & $0.86 \%$ \\
\hline Rzeszów & 572 & o & ०\% \\
\hline Szczecin & 882 & 22 & $2.49 \%$ \\
\hline Warszawa & 2,840 & 1 & $0.04 \%$ \\
\hline Wrocław & 1,790 & 15 & $0.84 \%$ \\
\hline Sum & 19,172 & 78 & \\
\hline
\end{tabular}

Source: own study based on the CDJAC (accessed September 30, 2020).

lowest percentage of dissenting opinions (except for $\odot \%$ ) in excise duty cases was recorded in 2010 (0.115\%). 866 judgements were issued in 2010, only 1 disagreeing.

Table 1 presents detailed data in this respect.

During the 15-year examined period, dissenting opinions were submitted on average 4.87 times for each VAC.

Most often, dissenting opinions from excise duty judgments were made by judges of the VAC in Szczecin (22 times), the least often by judges of VACs in Gorzów Wielkopolski, Kielce, and Warsaw (once). On the other hand, judges of VACs in Białystok, Kraków, Lublin, Opole, and Rzeszów never submitted dissenting opinions in excise duty matters.

It is worth emphasizing that the noticeably highest percentage of dissenting opinions in excise duty cases was recorded in the VAC in Szczecin (2.49\%). 882 cvs were 
issued there, up to 22 of them disagreed. In turn, the lowest percentage of dissenting opinions in the abovementioned cases was reported in the VAC in Warsaw (0.04\%). There were 2840 judgements issued there, and dissenting opinion was submitted to only 1 of them.

Table 2 presents detailed data in this respect.

\section{Qualitative Analysis}

The qualitative analysis of separate opinions submitted from the judgments of voivodship administrative courts in excise duty cases shows that 6 o out of 78 judgments were appealed against in cassation to the Supreme Administrative Court (further: "the SAC"). Out of this number, 39 cases brought before the Supreme Administrative Court resulted in a judgment and in 21 cases the complainant withdrew the cassation appeal.

Only 39 cases were subjected to detailed qualitative analysis (both in the first and second instance), because this group of decisions deciding the matter as to its substance had an impact on the solution of the research problem set out at the beginning. For the sake of clarity, the examined rulings were assigned to specific issues in the field of excise duty.

\section{III.1. Dissenting Opinions Submitted from VAC Judgments Issued in Cases of Formal Defects in Declarations of Buyers for the Purpose of Excise Goods}

According to the facts adopted by the VAC in Gorzów Wielkopolski in the judgment of February 23, 2010, ${ }^{7}$ the Director of the Customs Chamber upheld the decision of the first instance authority specifying tax liability in the excise duty towards a company dealing mainly in the wholesale of diesel gas, and also liquid gas adapted for heating purposes. In the invoices issued by the buyers of the latter type of gas, numerous deficiencies were revealed (e.g. no indication as to the amount, type and type of heating devices; no personal identity number or tax numbers).

In its justification, the customs authority referred to the content of the Regulation of the Minister of Finance of April 26, 2004 on exemptions from excise duty8 and more specifically its $\S 15$ para. 1, which stipulates that liquefied petroleum gas, propane, butane, and propane-butane mixtures shall be exempted from excise duty when used for purposes other than for driving motor vehicles.

This provision, among others, applies provided that the buyer declares that the purchased LPG is not intended for the propulsion of motor vehicles. In accordance with $\S 15$ para. 8 of the Regulation, this statement should contain at least the name of the buyer, personal identity number and tax number, the address of the buyer, specification of the quantity of LPG purchased, specification of the quantity, type, and type of heating

7 Judgment of the VAC in Gorzów Wielkopolski of February 23, 2010, case no. I SA/Go 558/o9,

CDJAC.

Consolidated text of Dz. U. 2018, item 2525, as amended, further: "regulation." 
devices owned and the place (address) where the devices are located, if it is other than the buyer's address, the date and place of making the declaration and signature of the person making the declaration. According to the appeal body, the contested statements lack elements that must necessarily be contained in the buyer's declaration to make the applicant entitled to an exemption from excise duty on this sale.

While repealing the contested decision, the VAC did not share the arguments of the authorities that the lack of any element of the buyer's statement specified in the regulation disqualifies this statement as incomplete. In the case at hand, the VAC considered such deficiencies as irrelevant errors.

In a dissenting opinion submitted from this judgment, the judge took the position that when making a sale of gas exempt from excise duty due to its intended use, the taxpayer is required to meet certain conditions and only after fulfilling them he/she will be entitled to such exemption. The taxpayer's use of the excise duty exemption is conditional upon the possession of declarations which, both in formal and material terms, are consistent with reality. Only completely completed declarations (in the strict sense) entitle the seller to a tax exemption. The judge emphasized that administrative courts are not entitled to recognize which elements should be included in statements and which should not. The judge did not indicate what in his opinion should be the exact content of the decision.

In a judgment of June 22, 2011, ${ }^{9}$ the Supreme Administrative Court set aside the judgment under appeal and remitted the case. The SAC did not note the reasons for submitting a dissenting opinion, however, it accepted the arguments contained therein. The judge argued that the provisions governing tax exemption should be interpreted strictly and that only deficiencies that do not prevent the verification of the legitimacy of a tax exemption should be considered insignificant. However, since the legislator requires that the statement includes both the first and last name, and personal identity number or tax numbers, it is against the law to assume that the lack of one of these elements is not a significant deficiency and that demonstrating the above rests with the taxpayer. As part of the authority's obligation to take all necessary actions to accurately clarify the facts and settle the matter, there is no obligation to look for reasons why the declarations do not meet the formal requirements and to justify the taxpayer's lack of diligence. It is the taxpayer selling the excise good, wishing to exercise his right to be exempt from this tax, who should first of all make efforts to gather reliable statements, and initiate appropriate evidence in the course of the proceedings.

In similar facts adopted by the VAC in Szczecin in the judgments of December $4,2013,{ }^{10}$ complaints against the decisions of the Director of the Customs Chamber

9 Judgment of the SAC of June 22, 2011, case no. I GSK 374/10, CDJAC.

10 Judgment of the VAC in Szczecin of December 4, 2013, case no. I SA/Sz 758/12, CDJAC;

Judgment of the VAC in Szczecin of 4 December 2013, case no. I SA/Sz 759/12, CDJAC; Judgment

of the VAC in Szczecin of December 4, 2013, case no. I SA/Sz 76o/12, CDJAC; Judgment of

the VAC in Szczecin of December 4, 2013, case no. I SA/Sz 761/12, CDJAC; Judgment of the

VAC in Szczecin of December 4, 2013, case no. I SA/Sz 762/12, CDJAC; Judgment of the

VAC in Szczecin of December 4, 2013, case no. I SA/Sz 763/12, CDJAC; Judgment of the 
upholding the decisions of the authority of the first instance determining the tax liability in excise duty were dismissed.

A dissenting opinion from these judgments, however, contained the opposite view, that the lack of any of the elements of the required buyer's statement would not prevent the seller of excise goods to benefit from the preferential tax rate. However, in these cases, the judge indicated what in his opinion should be the exact content of the decision, i. e. the repeal of the contested decisions from legal circulation as contrary to substantive law.

By judgments of April 15, 2015, ${ }^{11}$ the Supreme Administrative Court dismissed cassation complaints, disregarding the submission of a votum separatum.

In a similar factual and legal justification adopted by the VAC in Bydgoszcz in a judgment of April 28, 2015, ${ }^{12}$ the decision of the Director of the Customs Chamber annulled in full the decision of the first instance authority and determined the amount of the tax liability in the excise duty on the sale of diesel fuel for heating purposes as part of business activity carried out by the taxpayer. The customs authority applied a tax rate of 1,822 PLN / 1000 liters, thereby refusing the right to apply a preferential tax rate of 232 PLN / 1000 liters. The reason for the above resulted also from formal deficiencies found in the oil buyer's statements.

The VAC annulled the contested decision, stating that the content of the declarations should first of all be reviewed as to their usefulness in determining the information sought, who and for what purpose purchased the heating oil. This makes it possible to further determine the main issue: whether the heating oil was intended

VAC in Szczecin of December 4, 2013, case no. I SA/Sz 764/12, CDJAC; Judgment of the VAC in Szczecin of December 4, 2013, case no. I SA/Sz 765/12, CDJAC; Judgment of the VAC in Szczecin of December 4, 2013, case no. I SA/Sz 766/12, CDJAC; Judgment of the VAC in Szczecin of December 4, 2013, case no. I SA/Sz 767/12, CDJAC; Judgment of the VAC in Szczecin of December 4, 2013, case no. I SA/Sz 768/12, CDJAC; Judgment of the VAC in Szczecin of December 4, 2013, case no. I SA/Sz 769/12, CDJAC; Judgment of the VAC in Szczecin of December 4, 2013, case no. I SA/Sz 770/12, CDJAC; Judgment of the VAC in Szczecin of December 4, 2013, case no. I SA/Sz 771/12, CDJAC.

11 Judgment of the SAC of April 15, 2015, case no. I GSK 548/14, CDJAC; Judgment of the SAC of April 15, 2015, case no. I GSK 549/14, CDJAC; Judgment of the SAC of April 15, 2015, case no. I GSK 552/14, CDJAC; Judgment of the SAC of April 15, 2015, case no. I GSK 551/14, CDJAC; Judgment of the SAC of April 15, 2015, case no. I GSK 550/14, CDJAC; Judgment of the SAC of April 15, 2015, case no. I GSK 597/14, CDJAC; Judgment of the SAC of April 15, 2015, case no. I GSK 591/14, CDJAC; Judgment of the SAC of April 15, 2015, case no. I GSK 596/14, CDJAC; Judgment of the SAC of April 15, 2015, case no. I GSK 595/14, CDJAC; Judgment of the SAC of April 15, 2015, case no. I GSK 594/14, CDJAC; Judgment of the SAC of April 15, 2015, case no. I GSK 59o/14, CDJAC; Judgment of the SAC of April 15, 2015, case no. I GSK 593/14, CDJAC; Judgment of the SAC of April 15, 2015, case no. I GSK 598/14, CDJAC; Judgment of the SAC of April 15, 2015, case no. I GSK 592/14, CDJAC. 
for heating purposes. Minor irregularities that actually occurred (such as: illegible signature, unspecified type of heating device) may not affect the loss of tax preferences.

A dissenting opinion from this judgment contained considerations about the illegibility of the signature in the jurisprudence. It was indicated that the authority correctly questioned the abovementioned declarations as ineffective to use the preferential excise duty rate. The judge did not indicate what in his opinion should be the exact content of the decision.

In the judgment of the SAC of November 10, $2017^{13}$ dismissing the cassation complaint, the submission of a dissenting opinion was noted in the part of the justification - a brief presentation of the state of the case. Not referring directly to the dissenting opinion in the legal basis of the decision and its explanation, the SAC found that the first instance court did not fail to interpret the provisions specifying the requirements as to the content of the statements on the use of heating oil for heating purposes, the interpretation of which should take into account — differently from what was adopted by tax authorities - the purpose of these provisions, not just refer to their semantic understanding.

\section{III.2. Dissenting Opinions Submitted from VAC Judgments Issued in Cases Concerning the Taxation of Passenger Cars Converted into Other Types of Vehicles before Their First Registration in the Country}

In accordance with the facts adopted by the VAC in Gliwice in judgments of March 10, 2014, ${ }^{14}$ the decisions of the Director of the Customs Chamber upheld the decisions specifying the tax liability of a taxpayer conducting business activity and also tax arrears in the excise duty on the sale of sanitary vehicles before their first registration in the country. As part of business operations, the taxpayer bought new trucks and then converted them into sanitary vehicles, i. e. the number of seats for passengers was increased, truck bodies were lifted, and medical equipment was purchased for them. Customs authorities, applying the criteria contained in the Regulation of the Council of Ministers of September 4, 2015 on the Polish Classification of Products and Services ${ }^{15}$ and the definition of a passenger car contained in road traffic regulations, concluded that these vehicles are passenger cars, which means that their sale is subject to excise duty.

While repealing the contested decisions, the VAC found that the customs authorities had applied incorrect interpretations of the items contained in PCPS.

Dissenting opinions submitted from each judgment contained an unambiguous position stating that trucks converted into sanitary vehicles by the taxpayer are excise goods and, as a consequence, passenger cars. It was pointed out that based on the collected evidence in connection with the relevant PCPS codes, these vehicles could not

13 Judgment of the SAC of November 10, 2017, case no. I GSK 2028/15, CDJAC.

14 Judgment of the VAC in Gliwice of March 10, 2014, case no. III SA/Gl 1656/13, CDJAC; Judgment of the VAC in Gliwice of March 10, 2014, case no. III SA/Gl 1657/13, CDJAC; Judgment of the VAC in Gliwice of March 10, 2014, case no. III SA/Gl 1658/13, CDJAC. 
be considered mobile medical or dental clinics. The dissenting opinion also contained very detailed considerations on the abovementioned conceptual systematics, including references to dictionaries of foreign (borrowed) words. The judge did not indicate what in his opinion should be the exact content of the decision.

In the judgments of February 25, $2016^{16}$ dismissing cassation complaints, the SAC did not note in the substantiation of submitting separate opinions, however, it referred to the argumentation contained therein. The judge considered that the first instance court had issued correct decisions and that the vehicle's qualification was presented by the customs authorities in an incomplete and reasonable manner.

In a similar factual and legal justification adopted by the VAC in Gliwice in judgments of December 1, 2014, ${ }^{17}$ the decisions of the Director of the Customs Chamber upheld the decisions specifying the tax liability of a taxpayer conducting business activity and also tax arrears in the excise duty on the sale of sanitary vehicles before their first registration in the country. As in the previous case, the taxpayer, as part of his business activity, purchased new trucks and then rebuilt them into sanitary vehicles.

This time, the VAC dismissed the complaint and considered that "ambulances" should be classified under heading 8703 of the $\mathrm{CN}$ and should be treated as passenger cars within the meaning of Art. 100 paragraph 4 of the Act of December 6, 2008 on excise duty. ${ }^{18}$ However, it is impossible to classify the vehicles in question under $\mathrm{CN}$ heading 8705 according to PCPS (covering special-purpose motor vehicles other than those that were essentially built for the transport of persons or goods), since the explanatory note to this item indicates that it includes specially constructed, or adapted, motor vehicles equipped with various devices enabling the performance of some non-transport functions, and are therefore viewed as vehicles whose original purpose is other than transport.

Dissenting opinions from each judgment contained an unequivocal position stating that the vehicles at issue correspond to the description relating to heading 8705 of the $\mathrm{CN}$. This thesis was preceded by an even more comprehensive theoretical and legal analysis than in the case of previously submitted dissenting opinions. The judge indicated what in his opinion should be the exact content of the decision - due to the fact that the contested decision was burdened with many procedural and material defects, it was necessary to repeal it from legal circulation.

In the judgments of December 8, $2016^{19}$ revoking the appeals, the Supreme Administrative Court only in one of them noted submitting a dissenting opinion. ${ }^{20}$

16 Judgment of the SAC of February 25, 2016, case no. I GSK 1244/14, CDJAC; Judgment of the SAC of February 25, 2016, case no. I GSK 1245/14, CDJAC; Judgment of the SAC of February 25, 2016, case no. I GSK 1246/14, CDJAC.

Judgment of the VAC in Gliwice of December 1, 2014, case no. III SA/Gl 1076/14, CDJAC; Judgment of the VAC in Gliwice of December 1, 2014, case no. III SA/Gl 1016/14, CDJAC.

18 Consolidated text Dz. U. 2019, item 864, as amended, further: "AET".

19 Judgment of the SAC of December 8, 2016, case no. I GSK 853/15, CDJAC; Judgment of the SAC of December 8, 2016, case no. I GSK 1011/15, CDJAC. 
The judge did so not only in a concise presentation of the state of the case, but also in the legal basis of the resolution and its explanation, where he agreed with the view expressed in cvs that, under heading 8705 of the $\mathrm{CN}$, "Mobile medical clinics" the equipment of some ambulances is sometimes the same as that found in hospital intensive care rooms. However, in both judgments, the Supreme Administrative Court admitted the reasoning of the argument expressed in dissenting opinions, which led to the cassation nature of the decision.

In accordance with the facts adopted by the VAC in Wrocław in judgments of October 23, 2013, ${ }^{21}$ the Director of the Customs Chamber upheld the decision of the first instance authority determining excise duty liability for intra-Community acquisition of a passenger car. The taxpayer conducting business activity purchased the car in France, brought it to Poland and sold it. Based on the evidence gathered, it was established that the vehicle should be assigned to $\mathrm{CN}$ code 8703 as intended for the transport of persons and, as a consequence, was subject to excise duty, which the taxpayer did not pay.

When dismissing the complaint, the VAC confirmed the arguments brought by the customs authority.

In a separate dissenting opinion, the judge stated that he partially agreed with the views on the interpretation of the applicable laws. He did not clearly indicate what judgment should be given by the adjudication panel. Justifying the above, the judge stated that the decision whether the car in dispute, due to its objective design features, is intended primarily for the transport of persons requires, above all, an unequivocal determination of the features relevant to this qualification under $\mathrm{CN}$ heading 8703 and the explanatory notes to this heading that he owned the vehicle on the day of purchase.

By judgments of February 4, 2015, ${ }^{22}$ the SAC set aside the judgment under appeal and remitted the case. The SAC did not note in the statement of reasons for submitting a dissenting opinion. The court of second instance stated that the evidence proceedings carried out so far did not allow for an unequivocal assessment as to the basic purpose of the vehicle. According to the court of second instance, the cited notes show that for assessing the nature of the vehicle, the appearance and equipment of the interior of the vehicle is important from the point of view of the function performed by the vehicle, be it freight or personal, and this should be the focus of the body's activities. It is difficult to disagree with the party's claims that neither the appearance nor the interior equipment of the vehicle indicate that it is used as a passenger car.

21 Judgment of the VAC in Wrocław of October 23, 2013, case no. I SA/Wr 1336/13, CDJAC; Judgment of the VAC in Wrocław of October 23, 2013, case no. I SA/Wr 1337/13, CDJAC; Judgment of the VAC in Wrocław of October 23, 2013, case no. I SA/Wr 1335/13, CDJAC. Judgment of the SAC of February 4, 2015, case no. I GSK 613/14, CDJAC; Judgment of the SAC of February 4, 2015, case no. I GSK 612/14, CDJAC; Judgment of the SAC of February 4, 2015, case no. I GSK 528/14, CDJAC. 


\section{III.3. Dissenting Opinions Submitted from VAC Judgments Issued in Cases of Confirmation of an Overpayment of Excise Duty}

In accordance with the facts adopted by the VAC in Gdańsk in a judgment of March 12, $2009,{ }^{23}$ the Director of the Customs Chamber upheld the decision of the first instance authority refusing to declare an excise duty overpayment for the purchase of an intra-Community passenger car. The taxpayer purchased a passenger car in France and paid excise duty, taking the value of the vehicle at the purchase price specified in the contract as the tax base. The customs authorities determined the value of the vehicle, different than the taxpayer's, according to the July 2004 Info-Expert catalog.

The VAC upheld the complaint and annulled the contested decision. In the justification of the decision, it was emphasized that the tax authorities had breached the law in determining the amount of excise duty on the applicant's car. The amount of tax was determined disregarding the provision of Art. 82 paragraph 3 AET, which indicates that in the case of the acquisition of an intra-Community passenger car, the tax base is the amount that the buyer is obliged to pay. In the Court's opinion, the legislator clearly and unambiguously determined the value of the vehicle that should constitute the basis for calculating the excise duty due. It is the sum specified by the parties to the contract, which the buyer is obliged to pay for the vehicle purchased, and not the value calculated on the basis of a catalog.

The dissenting opinion submitted from this judgment contained an analysis of the legal effects of the judgment of the Court of Justice of the European Union (further: "CJEU") of January 18, $2007^{24}$ on the application of tax law by tax authorities. The judge who submitted it indicated that it was the taxpayer who should prove that the technical condition of the vehicle made it impossible to determine its market value, which resulted in the need to determine the value on the basis of the catalog. The votum separatum does not specify what the exact content of the decision should be.

In a judgment of August 31, 2010, ${ }^{25}$ the SAC annulled the contested decision and remitted the case. The court of second instance did not note in the substantiation of submitting dissenting opinions, however, and accepted the argumentation contained therein. The court of second instance found that the VAC violated the provisions of substantive law, i. e. Article 82 paragraph 3 AET and Article 90 of the Treaty establishing the European Economic Community of March 25, 1957, ${ }^{26}$ through their misinterpretation in the light of the abovementioned judgment of the CJEU.

Judgment of the VAC in Gdańsk of March 12, 2009, case no. I SA/Gd 870/o8, CDJAC.

24 Judgment of the CJEU of January 18, 2007, case no. C-313/05, LEX no. 207145.See also Krzysztof Lasiński-Sulecki, “Glosa do wyroku TS z dnia 18 stycznia 2007 r., C-313/o5," Przegląd

Podatkowy 4, 2007: 38-43. 
In turn, in accordance with the facts adopted by the VAC in Wrockaw in judgments of October 27, 2011, ${ }^{27}$ December 2, 2011, ${ }^{28}$ and December 7, 2011,29 the Director of the Customs Chamber upheld the decisions of the first instance authority refusing the taxpayer to declare an excise duty overpayment. A taxpayer conducting business activity in the field of electricity production and sale filed an application to the customs authority for a refund of overpaid excise duty together with an adjustment of the tax return. The basis for the above request was the judgment of the CJEU of February 12, $2009,{ }^{30}$ according to which the provisions of national law in the field of excise duty on electricity that are incompatible with Community law cannot be used as the basis for charging taxes, while taxes paid based on these provisions are refundable. In the opinion of the customs authorities, this argument is incorrect, because the failure by the national legislator to transpose the provisions of the Directive does not entitle it to refer directly to EU law.

While repealing the appealed decisions, the VAC indicated that in these cases Community interpretation of domestic law had to be applied. The court emphasized that the right to directly apply the directive without national provisions cannot be used by state authorities to limit the rights arising from national provisions.

In dissenting opinions submitted from these rulings, the judge noted that he shares the position expressed in the judgment cited by the taxpayer, which found incorrect the implementation of the Energy Directive by the Polish legislator, granting the electricity producer who sold electricity to the entity reselling electricity the right to a tax refund. However, in his opinion, it was justified not to issue a cassation decision but to submit a question to the Court of Justice of the European Union and to suspend court proceedings pursuant to Article $124 \S_{1}$ item 5 PBAC. The above judge justified the judicial caution related to the potential liability for damages of the Polish State for the operation of courts contrary to the principles of Community law.

In the judgments of the Supreme Administrative Court of May 29, $2013^{31}$ and May $16,2013^{32}$ dismissing the cassation complaint, the submission of a separate opinion was noted in the factual findings of justification..$^{33}$ Not referring to a dissenting opinion in the legal basis of the decision and its explanation, the SAC ruled that the first instance court had issued the correct decision in the case. On the other hand, in a judgment of the Supreme Administrative Court of November 27, 2013, ${ }^{34}$ it quashed

Judgment of the VAC in Wrocław of October 27, 2011, case no. I SA/Wr 1132/11, CDJAC; Judgment of the VAC in Wrocław of October 27, 2011, case no. I SA/Wr 1122/11, CDJAC.

Judgment of the VAC in Wrocław of December 2, 2011, case no. I SA/Wr 1131/11, CDJAC. Judgment of the VAC in Wrocław of December 7, 2011, case no. I SA/Wr 1133/11, CDJAC. Judgment of the CJEU February 12, 2009, case no. C-475/o7, LEX no. 485098. Judgment of the SAC of May 29, 2013, case no. I GSK 251/12, CDJAC; Judgment of the SAC of May 29, 2013, case no. I GSK 365/12, CDJAC. Judgment of SAC of May 16, 2013, case no. I GSK 358/12, CDJAC. The dissenting opinion was not explicitly referred to only in the justification to the judgment of the SAC of May 16, 2013, case no. I GSK 358/12, CDJAC. 
the contested judgment and remitted the case due to the violation of the provisions of the proceedings by the VAC. The cassation judgment does not refer to the dissenting opinion at all. It should be emphasized that in none of the above judgments did the Supreme Administrative Court comment at all on the question of a preliminary ruling.

In turn, in accordance with the facts adopted by the VAC in Szczecin in judgments of December 19, 2012, ${ }^{35}$ the Director of the Customs Chamber upheld the decisions of the authority of the first instance refusing to acknowledge the overpayment and determined the company's liability in excise duty for intra-Community acquisition. A taxpayer conducting business activity notified a planned intra-Community acquisition of lubricating oils, then purchased them and submitted a simplified declaration indicating the excise duty due in this respect. In the next application, the taxpayer applied for a declaration of overpaid excise duty. In the view of the appeal body, in light of national regulations, lubricating oils were harmonized excise goods, and their intra-Community acquisition was subject to excise duty at a reduced excise rate pursuant to $\S 2$ 2 point 2 in connection with item 2 of Annex 2 of the Regulation.

When dismissing the complaints, the VAC fully shared the position of the customs authority.

In dissenting opinions, the judge took a clear position that the VAC should issue a judgment revoking the decision. Justifying the above, the judge presented a comprehensive argument regarding the institution of overpayment. According to the voting judge, in the case subject to the Court's review, the decision of the tax authority, which also results directly from its content, was issued in the proceedings initiated by the party's application for acknowledging the overpayment, therefore it was unacceptable in this procedure to determine the tax liability. In this case, the subject of the body's examination were only the circumstances raised in the application for an overpayment, the facts related to the reasons for the correction of the tax return. The scope of the evidence proceedings carried out by the authority is therefore sufficient only to examine the application for overpayment and not to determine the amount of the liability.

By judgments of March 10, 2015, ${ }^{36}$ the Supreme Administrative Court set aside the judgment under appeal and remitted the case. The court of second instance did not note in the justification the submission of a dissenting opinion, nor did it refer to the institution of tax overpayment described by the judge in the votum separatum. He only stated that the VAC did not analyze the case in question, taking into account the

Judgment of the VAC in Szczecin of December 19, 2012, case no. I SA/Sz 487/12, CDJAC; Judgment of the VAC in Szczecin of December 19, 2012, case no. I SA/Sz 497/12, CDJAC; Judgment of the VAC in Szczecin of December 19, 2012, case no. I SA/Sz 498/12, CDJAC; Judgment of the VAC in Szczecin of December 19, 2012, case no. I SA/Sz 499/12, CDJAC. 
judgment of the CJEU of February 12, 2015,37 and did not address all the charges raised in the complaint.

In turn, in accordance with the facts adopted by the VAC in Bydgoszcz in the judgment of February 10, 2015, ${ }^{38}$ the Director of the Customs Chamber upheld the decision of the first instance authority refusing the taxpayer to declare an overpayment in excise duty. The justification argued that the company produced and then sold electricity to external end users and others (distributors), which is why it became an excise taxpayer, submitted an excise duty declaration and paid the tax on time. The customs authority, citing the SAC resolution of June 22, 2011, ${ }^{39}$ explained that within the meaning of $72 \S 1$ item 1 of the Act of August 29, 1997, the Tax Ordinance, ${ }^{40}$ an overpayment of excise duty paid for the sale of electricity does not apply when the entity, who paid the excise duty did not suffer any damage to property.

The VAC annulled the contested decision in its entirety due to the fact that the customs authority did not thoroughly examine the taxpayer's financial standing. In the Court's view, it was necessary to consider the assessment of the factual circumstances by an expert in order to be able to convincingly decide whether the wrongly paid excise duty had been transferred to entities to whom the complainant sold electricity.

A dissenting opinion submitted from this judgment contained considerations on the subject of the aforementioned resolution of the Supreme Administrative Court, making the refund of excise duty overpayment to producers of electricity for the sale of energy conditional upon damage to property. In the judgment of this judge, this state of affairs creates the risk of finding that the domestic courts are in breach of Community law. The dissenting opinion also contains a clear demand for the issue being the subject of the commented resolution to be resolved by the appropriate composition of the court (Article 269 PBAC).

In the judgment of September $15,2017^{41}$ setting aside the first instance judgment and dismissing the cassation complaint, the Supreme Administrative Court did not note in the statement of reasons the submission of a dissenting opinion, however, it explicitly referred to it. The court emphasized the general binding force of resolutions of administrative courts and the resulting effect prohibiting each composition of the administrative court to resolve cases in a manner contrary to the position contained in the resolution of the enlarged composition of the Supreme Administrative Court. Thus, it was considered that there was no need to apply Art. 269 PBAC. On the other hand, setting aside the judgment of the VAC was the result of a premature decision by the court on substantive law.

37 Judgment of the CJEU of February 12, 2015, case no. C-349/13, LEX no. 1638973.

38 Judgment of the VAC in Bydgoszcz of February 10, 2015, case no. I SA/Bd 893/14, CDJAC.

39 Resolution of the SAC of June 22, 2011, case no. I GPS 1/11, LEX no. 824345.

40 Consolidated text Dz. U. 2019, item 9oo, as amended, further: “TO.”

41 Judgment of the SAC of September 15, 2017, case no. I GSK 1265/15, CDJAC. 


\section{III.4. Dissenting Opinions Submitted from VAC Judgments Issued in Other Cases}

In accordance with the facts adopted by the VAC in Warsaw in its judgment of March $31,2015,{ }^{42}$ the company did not pay tax obligations arising from the decision issued to it by the Director of the Tax Control Office, so the Director of the Customs Chamber issued enforcement titles, however, enforcement of the company's assets proved to be ineffective. In view of the above, proceedings were initiated ex officio regarding the decision on liability for tax arrears due to the company's unpaid liability to a member of the management board. This led to the issuing by the Head of the Customs Office (maintained by the authority of the second instance) of a decision advising joint and several tax liability of the members of the management board for unpaid excise duty. In the justification, the authority argued that the bankruptcy petition had not been filed and that no company property from which enforcement would be possible had been indicated. This led to a statement about the lack of premises for releasing from liability of a member of the management board under Art. 116 § 1 TO.

When dismissing the complaint, the VAC shared the authority's assertions, and thus the factual findings in the case that on the date indicated the applicant had not submitted the said statement on the resignation from the function of a member of the company's management board, emphasizing that the assessment of the evidence provided must be made in the entirety of the collected evidence and taking into account all event sequences and logical principles of reasoning.

A dissenting opinion submitted from this judgment contained considerations on the principles of assessment of evidence in administrative proceedings. It clearly indicated which decision the judge filing for it supports, i.e. the annulment of the contested decision due to the lack of evidence.

In the judgment of August 31, $2017^{43}$ dismissing the cassation complaint, the Supreme Administrative Court did not note in the justification of submitting a dissenting opinion. The judge merely decided that the first instance court issued the correct decision and the premises for the liability of the management board members for the company's tax arrears were met.

In accordance with the facts adopted by the VAC in Gliwice in judgments of December 28, 2011, ${ }^{44}$ the Director of the Customs Chamber upheld the decision of the authority of the first instance determining the amount of excise duty liability arising from the acquisition of harmonized intra-Community excise goods (lubricating oil). The lubricating oil acquired by the company was not intended for heating or propulsion purposes, as the company used it for the production of bolts and as a material reducing friction press, rolling mill, and machining machines. The authority argued that excise duty taxation in Community law is based mainly on the provisions of legal acts in force

42 Judgment of the VAC in Warsaw of March 31, 2015, case no. V SA/Wa 2056/14, CDJAC.

43 Judgment of the SAC of August 31, 2017, case no. I GSK 1384/15, CDJAC.

44 Judgment of the VAC in Gliwice of December 28, 2011, case no. III SA/Gl 1223/11, CDJAC;

Judgement of the VAC in Gliwice of December 28, 2011, case no. III SA/Gl 1224/11, CDJAC. 
indirectly, i. e. on The Council Directive 92/12/EEC of February 25, 1992 on the general arrangements for products subject to excise duty and on the holding, movement, and monitoring of such products, ${ }^{45}$ which sets out the general conditions for the taxation of products found to be excise duty, their storage, movement and control, and on The Council Directive 2003/96/EC of October 27, 2003 restructuring the Community framework for the taxation of energy products and electricity, ${ }^{46}$ regulating the scope of energy products, the level of taxation, and the exemption and reduction of excise duty rates for energy products and electricity. In the opinion of customs authorities, lubricating oils used for purposes other than motor fuel or heating fuels are subject to excise duty, which is explicitly allowed by the provisions of these Directives.

When dismissing the complaints, the VAC fully shared the position of the authority. In the submitted dissenting opinions, the judge took the position that the provision of Art. 2 clause 4 point b of the Energy Directive is unconditional and precise in relation to the Member State and the obligation it imposes is clearly stated-lubricating oils used for purposes other than motor fuel or heating fuels should not be subject to excise duty, since from April 1, 2010 according to Art. 1 clause 1 lit. a of Council Directive 2008/118/EC of December 16, 2008 concerning the general arrangements for excise duty and repealing Directive 92/12/EEC, ${ }^{47}$ repealing the horizontal directive, energy products are excise goods which, as regards excise duty levied directly or indirectly on the consumption of this product, are subject to the general principles laid down in this directive. The judge did not indicate what in his opinion should be the exact content of the decisions.

By judgments of June 9, 2015, ${ }^{48}$ the Supreme Administrative Court set aside the judgment under appeal and remitted the case. The SAC did not note in the statement of reasons for submitting a dissenting opinion. However, it pointed out, in accordance with the position expressed in the votum separatum, that the VAC violated Art. 134 § 1 PBAC, without assessing the contested decision in the context of the compliance of the solutions adopted in national law with the provisions of Art. 3 para. 3 of the horizontal Directive. The VAC was required to carry out a full review of the contested decision in terms of its compliance with applicable national and Community law. Even where the applicant did not refer to specific provisions of national law which, in her view, 'increased formalities when crossing the border in trade between Member States', it was for the VAC to consider that point.

In accordance with the facts adopted by the VAC in Olsztyn in judgments of March 29, 2012,49 the Director of the Customs Chamber upheld the decision of the authority of the first instance specifying the date of the customs debt, the amount of excise duty,

45 Dz. U. L 76 of March 23, 1992, further: "Horizontal Directive".

46 Dz. U. L 283/51 of October 31, 2003, further: "Energy Directive".

47 Dz. U. L 9/12 of January 14, 2009.

48 Judgment of the SAC of June 9, 2015, case no. I GSK 425/15, CDJAC; Judgment of the SAC of June 9, 2015, case no. I GSK 424/15, CDJAC.

49 Judgment of the VAC in Olsztyn of March 29, 2012, case no. I SA/Ol 72/12, CDJAC; Judgment of the VAC in Olsztyn of March 29, 2012, case no. I SA/Ol 74/12, CDJAC. 
fuel charge, and tax on goods and services in connection with the removal of customs supervision of diesel fuel brought into the customs territory of the Community. As part of business operations, the taxpayer crossed the border by coach, importing fuel in the vehicle's tank. This fuel was duty-free, with the proviso that it was transported in a regular fuel tank. According to the entry reports to Poland, the driver of the vehicle declared the amount of fuel in the tank as between 460 to 470 liters. According to the coach manufacturer's information the factory tank held 390 liters.

The VAC, annulling the contested decision, stated that the tax authorities had not demonstrated that the applicant had removed fuel from customs supervision. The court pointed out that when the case was re-examined, the customs authority should have determined whether, in addition to the standard tank, the coach was equipped with an additional non-standard tank. Under these circumstances, customs officers and drivers should be questioned as witnesses, i. e. persons who were responsible for the content of the reports from customs control. In addition, the authority should question customs officers and drivers to clarify contradictions regarding the amount of fuel transported.

In dissenting opinions, the judge took a clear position, noting that the failure of the authority to provide evidence should not result in the annulment of the contested decision. When conducting business activity in the field of passenger transport by bus and taking advantage of customs and tax exemptions for fuel imported in a standard tank, it was the responsibility of the parties to determine the tank capacity accurately. Knowing this capacity and the quantity of diesel oil declared upon entering a country's territory, any doubts arising as to the notifications made to this effect should be explained on a regular basis and immediately by the professional entrepreneur engaged in transport activities.

With judgments of October 16, 2013, ${ }^{50}$ the Supreme Administrative Court set aside the appeals and remanded the case. The Supreme Administrative Court did not note the reasons for submitting dissenting opinions. However, the arguments expressed in the votum separatum were correct. The court of second instance stated that the amount of reported fuel compared to the capacity of a standard tank installed in the bus constituted the basis for determining the amount of customs and tax duties. The driver, when reporting the introduction of fuel into the customs territory of the Community, was required to provide the actual quantity, and not only the fuel in the ordinary tank. Therefore, in a situation where the amount of fuel imported into the Community provided by the bus driver did not raise any doubts, the determination of import duties on the fuel declared over the capacity of a standard tank was justified.

In none of the cases examined in point III.1-III.4., did the applicant, while filing a cassation complaint to the Supreme Administrative Court, make allegations as to the fact or content of the submitted dissenting opinion.

$5^{\circ}$ Judgment of the SAC of October 16, 2013, case no. I GSK 949/12, CDJAC; Judgment of the SAC of October 16, 2013, case no. I GSK 951/12, CDJAC. See more Wiktor Poniewierka, Prawo celne. Komentarz. (Warszawa, 2015). 


\section{Summary of the Results}

Quantitative research allowed to make the most important findings.

First of all, judges of the VAC submit cvs extremely rarely in excise duty cases about 5 times per year, and in the years 2004-2018 out of 19,172 judgments issued, dissenting opinions were submitted to only 78 of them, which constitutes less than $0.5 \%$ of the total. There is no upward or downward trend in this respect.

Second, the occasional nature of dissenting opinions also applies to individual voivodship administrative courts. The highest number of cvs was submitted by judges in Szczecin (22) and the least in Białystok, Kraków, Lublin, Opole, Rzeszów (o).

Third, a small number of votum separatum submitted from the rulings of the VAC regarding excise duty may indicate the predictability of the judicial process of applying tax law and, consequently, the implementation of the constitutional principle of legal certainty at the stage of first instance. Moreover, it may also indicate the unambiguity of tax law and, consequently, the implementation of the constitutional principle of correct legislation at the stage of first instance. It needs to be emphasized that it is assumed that this branch of law is one of the most inconsistent and unstable, both in the process of its creation and application.

Quantitative research also allowed to make the following important findings.

First, it is not possible to clearly define the types of excise duty issues in which only dissenting opinions from VAC judgments are submitted. The recurring issues can undoubtedly be those of formal deficiencies in the declarations of buyers concerning the purpose for which excise goods are used, the taxation of passenger cars converted into other types of vehicles before their first registration in the country, or the determination of overpaid excise duty. Often, dissenting opinions are submitted on the effectiveness of Community tax law in the national legal order. On the other hand, the type of dissenting opinion is constant. Of all 39 VAC judgments examined (100\%), a dissenting opinion was submitted from the entire judgment, while in no case was a dissenting opinion delivered only from the justification (o\%).

What is more, the content of the dissenting opinion is more differentiated. In $80 \%$ of the cases examined, the judge submitting a dissenting opinion clearly indicated what final judgment should be issued in her/his opinion in a given case. The remaining dissenting opinions $(20 \%)$ contained only a polemic with the legal findings of the adjudication panel.

Second, in none of the cases examined ( $\%$ ) did the applicant, submitting a cassation complaint to the Supreme Administrative Court, make allegations as to the fact or content of the submitted dissenting opinion.

Third, in $56 \%$ of the cases examined, the Supreme Administrative Court issued a cassation judgment, thus accepting as valid arguments presented by the judge in the votum separatum. This element of the judgment in which the SAC referred to the dissenting opinion should be emphasized. In the constituent part of the judgment, i. e. in a concise presentation of the state of the case, the SAC recorded the submission 
of a dissenting opinion only in 9 judgments ( $23 \%$ of cases). On the other hand, in the constituent part of the judgment - the legal basis of the decision and its explanationthe SAC referred to the arguments expressed in a separate opinion in 16 judgments $(41 \%$ of cases). Thus, in the indicated parts of the 23 judgments, the Supreme Administrative Court did not refer to arguments of votum separatum ( $59 \%$ of cases). The manner of addressing dissenting opinion in SAC judgments is more constant. Of 16 judgments, in which the dissenting opinion and its explanation were referred to, only in one of them the Supreme Administrative Court referred to cvs directly, considering the view expressed there as justified (6\%). In the remaining 15 cases, the court of second instance referred to the views indirectly, adopting them as its own (94\%).

The research hypothesis put forward at the beginning of the study was not positively validated in its entirety. The research findings show that dissenting opinions from Polish voivodship administrative court judgments issued in cases of excise duty fulfill the documentary and guarantee function to an average degree.

The analysis certainly does not exhaust all issues related to dissenting opinions in the jurisprudence of administrative courts in tax matters and their documentary and guarantee function. It would be worth examining dissenting opinions in judgments concerning other taxes, also in terms of comparative law. ${ }^{51}$ What is more, it would also be worth examining whether dissenting opinions from judgments issued by administrative courts on excise duty also influenced the development of the doctrine of tax law and publications in this area. Due to the nature of the study, of which the article is part, these issues could not be addressed here. However, further work is planned in this area.

\section{Bibliography}

"Central Database of Judgments of Administrative Courts". Accessed October 1, $202 \mathrm{O}$. http://orzeczenia.nsa.gov.pl.

"Information of the Chairman of the Judicial Information Department of the Supreme Administrative Court of 16.12.2019 reference number WIS.050.676.2019," own collection.

Adler, John "Dissent in Courts of Last Resort: Tragic Choices?" Oxford Journal of Legal Studies, 20 (2000): 221-46.

Bartoszewski, Jerzy, Zdania odrębne w procesie karnym. (Warszawa, 1973).

Bojańczyk, Antoni, “Zdania odrębne w postępowaniu karnym”. Forum Prawnicze 12,” (2012): $3^{-12 .}$

Epstein, Lee, Landes William.M., Posner Richard A., Why (and When) Judges Dissent: a Theoretical and Empirical Analysis. John M. Olin Law \& Economics Working Paper No. 510, 2010.

51 I have examined dissenting opinions in judgments concerning direct tax cases using mostlythe quantitative analysis. See Patryk Kowalski, "Documentary and guarantee function of Polish administrative court's dissenting opinions in direct tax cases," European Journal of Behavioral Sciences 2(4), 2020: 19-30, https://doi.org/10.33422/ejbs.v2i4.3oo. 
Fisher, Rodney, "Judicial dissent in taxation cases: The incidence of dissent and factors contributing to dissent." eJournal of Tax Research 13, (2015): 470-90.

Judgment of the CJEU February 12, 2009, case no. C-475/o7, LEX no. 485098. Judgment of the CJEU of February 12, 2015, case no. C-349/13, LEX no. 1638973. Judgment of the CJEU of January 18, 2007, case no. C-313/O5, LEX no. 207145. Judgment of the SAC of March 10, 2015, case no. I GSK 347/13, CDJAC. Judgment of the SAC of March 10, 2015, case no. I GSK 350/13, CDJAC. Judgment of the SAC of March 10, 2015, case no. I GSK 351/13, CDJAC. Judgment of the SAC of March 10, 2015, case no. I GSK 353/13, CDJAC. Judgment of the SAC of November 10, 2017, case no. I GSK 2028/15, CDJAC. Judgment of the SAC of April 15, 2015, case no. I GSK 548/14, CDJAC. Judgment of the SAC of April 15, 2015, case no. I GSK 549/14, CDJAC. Judgment of the SAC of April 15, 2015, case no. I GSK 550/14, CDJAC. Judgment of the SAC of April 15, 2015, case no. I GSK 551/14, CDJAC. Judgment of the SAC of April 15, 2015, case no. I GSK 552/14, CDJAC. Judgment of the SAC of April 15, 2015, case no. I GSK 590/14, CDJAC. Judgment of the SAC of April 15, 2015, case no. I GSK 591/14, CDJAC. Judgment of the SAC of April 15, 2015, case no. I GSK 592/14, CDJAC. Judgment of the SAC of April 15, 2015, case no. I GSK 593/14, CDJAC. Judgment of the SAC of April 15, 2015, case no. I GSK 594/14, CDJAC. Judgment of the SAC of April 15, 2015, case no. I GSK 595/14, CDJAC. Judgment of the SAC of April 15, 2015, case no. I GSK 596/14, CDJAC. Judgment of the SAC of April 15, 2015, case no. I GSK 597/14, CDJAC. Judgment of the SAC of April 15, 2015, case no. I GSK 598/14, CDJAC. Judgment of the SAC of September 15, 2017, case no. I GSK 1265/15, CDJAC. Judgment of the SAC of May 16, 2013, case no. I GSK 358/12, CDJAC. Judgment of the SAC of October 16 2013, case no. I GSK 949/12, CDJAC. Judgment of the SAC of October 16, 2O13, case no. I GSK 951/12, CDJAC. Judgment of the SAC of June 22, 2011, case no. I GSK 374/10, CDJAC. Judgment of the SAC of February 25, 2016, case no. I GSK 1244/14, CDJAC. Judgment of the SAC of February 25, 2016, case no. I GSK 1245/14, CDJAC. Judgment of the SAC of February 25, 2016, case no. I GSK 1246/14, CDJAC. Judgment of the SAC of November 27, 2013, case no. I GSK 231/12, CDJAC. Judgment of the SAC of May 29, 2013, case no. I GSK 251/12, CDJAC. Judgment of the SAC of May 29, 2013, case no. I GSK 365/12, CDJAC. Judgment of the SAC of August 31, 2010, case no. I GSK 1044/15, CDJAC. Judgment of the SAC of August 31, 2017, case no. I GSK 1384/15, CDJAC. Judgment of the SAC of February 4, 2015, case no. I GSK 528/14, CDJAC. Judgment of the SAC of February 4, 2015, case no. I GSK 612/14, CDJAC. Judgment of the SAC of February 4, 2015, case no. I GSK 613/14, CDJAC. Judgment of the SAC of December 8, 2016, case no. I GSK 1011/15, CDJAC. Judgment of the SAC of December 8, 2016, case no. I GSK 853/15, CDJAC. Judgment of the SAC of June 9, 2015, case no. I GSK 424/15, CDJAC. Judgment of the SAC of June 9, 2015, case no. I GSK 425/15, CDJAC. 
Judgment of the VAC in Bydgoszcz of February 14, 2015, case no. ISA/Bd 893/14, CDJAC. Judgment of the VAC in Bydgoszcz of April 28, 2015, case no. I SA/Bd 167/15, CDJAC. Judgment of the VAC in Gdańsk of March 12, 20o9, case no. I SA/Gd 870/o8, CDJAC. Judgment of the VAC in Gliwice of March 10, 2014, case no. III SA/Gl 1656/13, CDJAC. Judgment of the VAC in Gliwice of March 10, 2014, case no. III SA/Gl 1657/13, CDJAC. Judgment of the VAC in Gliwice of March 10, 2014, case no. III SA/Gl 1658/13, CDJAC. Judgment of the VAC in Gliwice of December 28, 2011, case no. III SA/Gl 1223/11, CDJAC. Judgment of the VAC in Gliwice of December 28, 2011, case no. III SA/Gl 1224/11, CDJAC. Judgment of the VAC in Gorzów Wielkopolski of February 23, 2010, case no. I SA/Go 558/og, CDJAC.

Judgment of the VAC in Olsztyn of March 29, 2012, case no. I SA/Ol 72/12, CDJAC. Judgment of the VAC in Olsztyn of March 29, 2012, case no. I SA/Ol 74/12, CDJAC. Judgment of the VAC in Szczecin of December 19, 2012, case no. I SA/Sz 487/12, CDJAC. Judgment of the VAC in Szczecin of December 19, 2012, case no. I SA/Sz 497/12, CDJAC. Judgment of the VAC in Szczecin of December 19, 2012, case no. I SA/Sz 498/12, CDJAC. Judgment of the VAC in Szczecin of December 19, 2012, case no. I SA/Sz 499/12, CDJAC. Judgment of the VAC in Szczecin of December 4, 2013, case no. I SA/Sz 769/12, CDJAC. Judgment of the VAC in Szczecin of December 4, 2013, case no. I SA/Sz 770/12, CDJAC. Judgment of the VAC in Szczecin of December 4, 2013, case no. I SA/Sz 758/12, CDJAC. Judgment of the VAC in Szczecin of December 4, 2013, case no. I SA/Sz 759/12, CDJAC. Judgment of the VAC in Szczecin of December 4, 2013, case no. I SA/Sz 76o/12, CDJAC. Judgment of the VAC in Szczecin of December 4, 2013, case no. I SA/Sz 761/12, CDJAC. Judgment of the VAC in Szczecin of December 4, 2013, case no. I SA/Sz 762/12, CDJAC. Judgment of the VAC in Szczecin of December 4, 2013, case no. I SA/Sz 763/12, CDJAC. Judgment of the VAC in Szczecin of December 4, 2013, case no. I SA/Sz 764/12, CDJAC. Judgment of the VAC in Szczecin of December 4, 2013, case no. I SA/Sz 765/12, CDJAC. Judgment of the VAC in Szczecin of December 4, 2013, case no. I SA/Sz 766/12, CDJAC. Judgment of the VAC in Szczecin of December 4, 2013, case no. I SA/Sz 767/12, CDJAC. Judgment of the VAC in Szczecin of December 4, 2013, case no. I SA/Sz 768/12, CDJAC. Judgment of the VAC in Szczecin of December 4, 2013, case no. I SA/Sz 771/12, CDJAC. Judgment of the VAC in Warsaw of March 31, 2015, case no. V SA/Wa 2056/14, CDJAC. Judgment of the VAC in Wrocław of December 2, 2011, case no. I SA/Wr 1131/11, CDJAC. Judgment of the VAC in Wrocław of October 23, 2013, case no. I SA/Wr 1336/13, CDJAC. Judgment of the VAC in Wrocław of October 23, 2013, case no. I SA/Wr 1337/13, CDJAC. Judgment of the VAC in Wrocław of October 23, 2013, case no. I SA/Wr 1335/13, CDJAC. Judgment of the VAC in Wrocław of October 27, 2011, case no. I SA/Wr 1132/11, CDJAC. Judgment of the VAC in Wrocław of October 27, 2011, case no. I SA/Wr 1122/11, CDJAC. Judgment of the VAC in Wrocław of December 7, 2011, case no. I SA/Wr 1133/11, CDJAC. Judgment of the VAC in Gliwice of December 1, 2014, case no. III SA/Gl 1076/14, CDJAC. Judgment of the VAC in Gliwice of December 1, 2014, case no. III SA/Gl 1016/14, CDJAC. Kowalski Patryk, "Documentary and Guarantee Function of Polish Administrative Court's Dissenting Opinions in Direct Tax Cases." European Journal of Behavioral Sciences 2(4), 2020: 19-30, https://doi.org/10.33422/ejbs.v2i4.30o. 
Lasiński-Sulecki Krzysztof, "Glosa do wyroku TS z dnia 18 stycznia 2007 r., C-313/o5”. Przegląd Podatkowy 4, 2007: 38-43.

Poniewierka Wiktor, Prawo celne. Komentarz. (Warszawa, 2015).

Resolution of SAC of June 22, 2011, case no. I GPS 1/11, LEX no. 824345.

The Act of August 29, 1997 - Tax Ordinance, consolidated text Dz. U. 2019, item 9oo, as amended.

The Act of August 30, 2002 Law on Proceedings Before Administrative Courts, consolidated text of Dz. U. 2019, item 2325, as amended.

The Act of December 6, 2008 on Excise Duty, consolidated text Dz. U. 2019, item 864, as amended.

The Council Directive 2003/96/EC of October 27, 2003 restructuring the Community framework for the taxation of energy products and electricity, Dz. U. L 283/51 of October 31, 2003.

The Council Directive 2008/118/EC of December 16, 2008 concerning the general arrangements for excise duty and repealing Directive 92/12/EEC, Dz. U. L 9/12 of January 14, 2009.

The Council Directive 92/12/EEC of February 25, 1992 on the general arrangements for products subject to excise duty and on the holding, movement and monitoring of such products, Dz. U. L 76 of March 23, 1992.

The Regulation of the Council of Ministers of September 4, 2015 on the Polish Classification of Products and Services, consolidated text Dz. U. 2015, item. 1676, as amended.

The Regulation of the Minister of Finance of April 26, 2004 on exemptions from excise duty, consolidated text of Dz. U. 2018, item 2525, as amended.

The Treaty establishing the European Economic Community of March 25, 1957, Dz. Urz. UE C 321 E 2006.

Wojciechowski Maciej, Spory sędziowskie. Zdania odrębne w polskich sądach. (Gdańsk, 2019).

Zdziennicki Bohdan, "Zdania odrębne w orzecznictwie polskiego Trybunału Konstytucyjnego", in Księga XX-lecia orzecznictwa Trybunału Konstytucyjnego, ed. Marek Zubik, 135-58. (Warszawa, 20o6).

Patryk Kowalski is an Assistant Professor at the Department of Financial Law, Faculty of Law and Administration, University of Łódź. 


\title{
Розбіжні Думки в Рішеннях Польських Адміністративних Судів у Справах про Акцизний Збір
}

\author{
Патрик Ковальски \\ доцент \\ Університет міста Лодзь, Польща
}

\begin{abstract}
Анотація
Ця стаття описує результати дослідження розбіжних думок, виданих суддями адміністративних судів у справах про акцизний збір в 2004-2018 роках. Аналіз охоплює рішення всіх 16 адміністративних судів Польщі, виданих за вказаний період. Рішення згруповані за критеріями видавця, зокрема 78 судових рішень видані адміністративними судами у справах про акцизний збір, а 6о рішень видані Верховним Адміністративним Судом в результаті касаційних процедур. Кількісний аналіз показав, що судді адміністративних судів у справах про акцизний збір розбіжні думки видають вкрай рідко-близько п'яти на рік. За період 2004-2018 років 3-поміж 19172 рішень, лише до 78 з них були видані розбіжні думки, що складає приблизно о,5\% від загальної кількості. Дослідження також показало, що у 41\% випадках Верховний Адміністративний Суд посилався на видані розбіжні думки як підстави задоволення касаційних скарг.
\end{abstract}

Ключові слова: акцизний збір, адміністративні суди, податкове право, розбіжна думка, votum separatum 